\title{
OVULIFEROUS STRUCTURES OF TAXUS CANADENSIS .
}

CONTRIBUTIONS FROM THE HULL BOTANICAL LABORATORY 267

A. W. DUPLER

(WITH PLATE XXIII AND SIXTY FIGURES)

\section{Introduction}

Following a recent paper (13) in which the writer gave a description of the staminate structures of Taxus canadensis Marsh., this paper deals with the ovuliferous structures, namely, the primary shoot, the secondary shoot, and the ovule, describing both the development and vascular features, together with a discussion of the morphological questions raised by these structures. The purpose in this investigation was twofold: (I) to compare T. canadensis with the European T. baccata, and (2) to look for new evidence bearing on the morphological problems of these structures in the genus. While no pretense of finality is made in this connection, it is thought that some additional evidence has been secured bearing on these problems. Since the female gametophyte has already been described (I2), only such reference is made to it as may be necessary. For a statement as to materials and methods, the reader is referred to previous papers $(\mathbf{1 2}, \mathbf{1 3})$.

\section{Historical}

Taxus has engaged the interest of botanists for a long time, the ovulate features, the gametophytes, and the early embryogeny especially receiving attention. The literature dealing with the ovulate structures is quite extensive, much of it being found in connection with descriptions and discussions of other conifers, and is based almost entirely upon $T$. baccata, very little dealing specifically with $T$. canadensis. The two forms are similar (6), and much which has been written will apply equally well to both forms. It would be impracticable to include a complete summary of all that has been published on the subject, a general summary sufficing, 
more complete references being available in the accounts of Strasburger (35), Radais (24), and Worsdell (39).

The earlier work was based largely on external features, and attempted to homologize the structures with those of the angiosperm flower. This attempt seemingly persisted much later with Taxus than with most other conifers, the gymnospermy of Taxus not being quite so soon recognized as in other forms. The bulk of the literature deals with the more theoretical questions, the actual descriptive work not being so extensive. The discussion of the literature will be presented in the text of the paper, in connection with the several topics, in this way avoiding repetition and presenting each topic in more complete form.

\section{Ovuliferous bud}

As previously pointed out (I3), three types of buds are formed in the axils of the leaves of a current season's shoot, namely, vegetative, staminate, and ovuliferous. The differentiation of the last is first recognized by the appearance of the rudiment of a secondary axis in the axil of one of its uppermost scales (fig. I), this rudiment appearing early in July. The ovuliferous bud begins early in the spring, as a conical rudiment in the axil of a young leaf, shortly after the beginning of the growth of the vegetative shoot, forming usually nearer the tip than the staminate buds. STRASBURGer (36) found the first differentiation of the ovuliferous bud in T. baccata to occur about August I. The structure can be distinguished by external features with certainty only when the ovule has reached such size as to protrude beyond the scales, usually not until spring. JäGER (I5) says that the ovuliferous bud of $T$. baccata is evident about February I, being slightly yellowish, and the vegetative bud being reddish brown; but this is hardly a safe criterion, owing to color variations.

\section{Primary shoot}

General FEATUREs.-The ovuliferous organ in Taxus consists of two structures: the primary ovuliferous branch, or, as it is more generally known, the primary shoot; and the secondary shoot on which the ovule is borne. The primary shoot arises directly 
in the axil of the leaf, and, as STRAsburger (35) pointed out for $T$. baccata, begins with two transverse scales, following which are a number of scales in spiral order, in the axil of one (or two) of
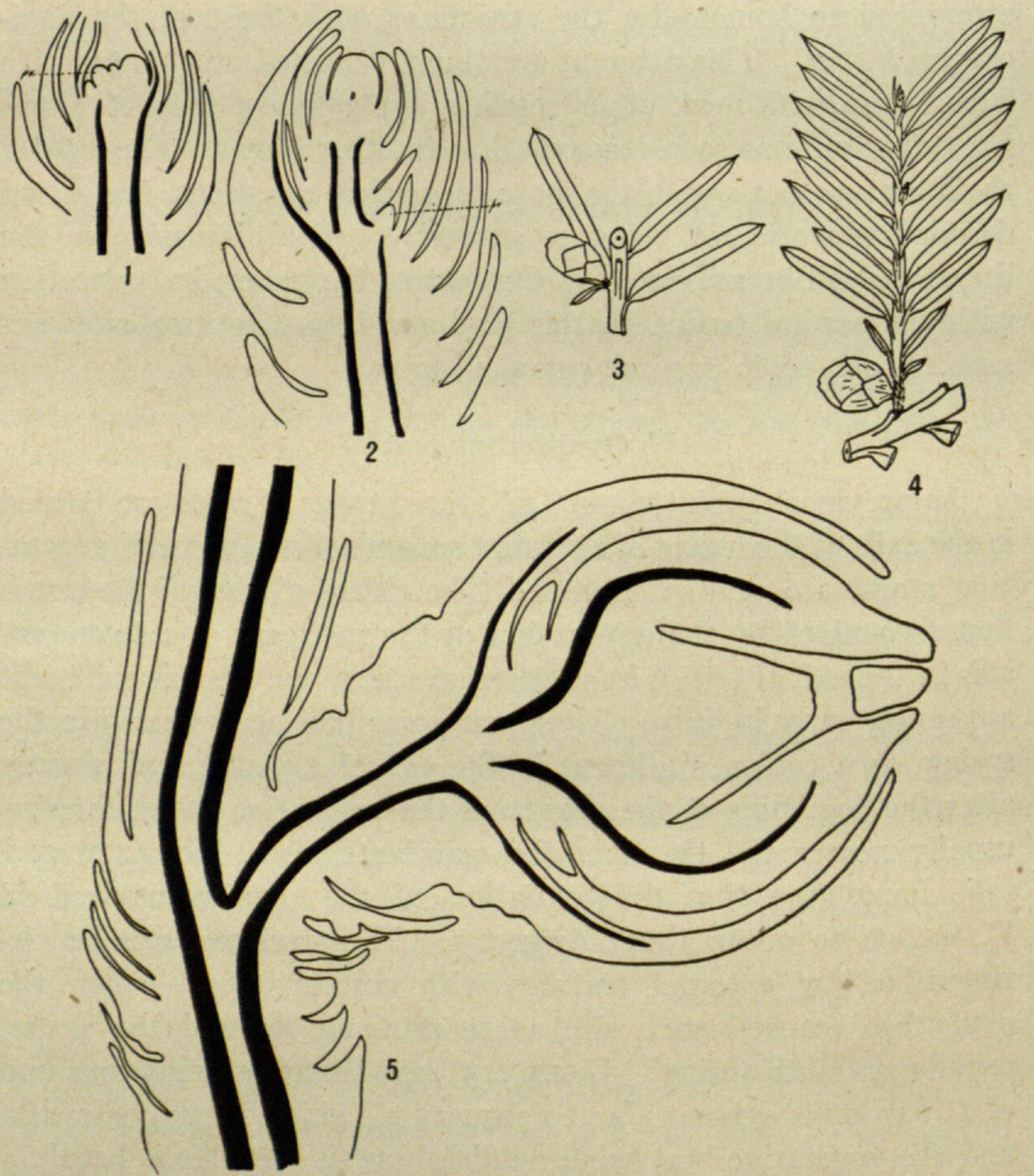

FIGS. I-5.-Fig. I, long section of primary shoot showing rudiment of secondary shoot; fig. 2, secondary shoot with young ovule and primary axis tip pushed to side; fig. 3, primary shoot which has developed two small leaves, shown below ovule; fig. 4, primary shoot which has become functionally vegetative, showing ovule at base; fig. 5, median longitudinal section of primary shoot, secondary shoot, and ovule, such as fig. 4 ; figs. $1,2, \times_{24}$; fig. $5, \times_{17}$.

which the secondary shoot (or shoots) arise. The scales of the primary shoot are very similar to the scales of the staminate 
strobilus already described (13), having very thick epidermal walls, especially on the outer surface, stomata on the inner surface, and rather large air spaces. They are brownish and lack chlorophyll.

During its first season the primary shoot is a dwarf branch of limited growth, and the development of the secondary shoot results in its tip becoming pushed aside (fig. 2) and remaining dormant for a time. Externally this gives the appearance of a single structure with a terminal ovule, a situation which may explain some of the earlier views as to the position of the ovule. VAN TIEghem (37) apparently was the first to point out this behavior of the primary axis. According to Schumann (3I), and also PILGer (23), the primary axis ends blindly, and the so-called tip of the primary shoot is the knob of a reduced side shoot which may at times grow out to form a second secondary shoot. When this occurs the primary axis may form a short knob between the two secondary shoots. This view does not agree with the facts and has received but little support.

SECOND SEASON'S GROWTH.-The tip of the primary shoot remains dormant until the next spring, when its growth is renewed, resulting either in its continuation as a dwarf structure, as in the first season, or in its growth as a leafy shoot, like that from the ordinary vegetative bud, a fact first noted for T. baccata by STRASBURGER (35). This leafy shoot may bear only a few small leaves (fig. 3) and develop no further during the second season, the subsequent behavior of such small shoots not being known. It also may develop as an ordinary leafy branch, differing in no way from other leafy branches except in bearing the secondary shoot at its base (figs. 4, 5), and, like any other vegetative branch, bearing vegetative and reproductive buds of the next season. Occasionally the primary axis remains dormant as a vegetative bud for a season or more. In such cases the reproductive nature of the first season can be told only by the scars of the old secondary shoot (fig. 6). Normally, however, the primary shoot continues its dwarf and reproductive character for the second and later seasons, producing a few scales as in the preceding season, with one or two new secondary shoots on the new growth. It has been generally assumed that the primary shoot produces fruiting structures for only one 
season, and that the maturity of the secondary shoot with the ovule results in the death of the primary shoot as well. This is not the normal situation, as usually only the secondary shoot with the ovule drops from the primary shoot, which remains in the axil of the leaf, a branch scar showing the place of detachment at the secondary shoot from the primary shoot (fig. 6). Detachment of the secondary shoot is probably accomplished normally by the formation of an absciss layer across the base of the shoot. The region of abscission is marked by a narrow layer of platelike cells, rich in protoplasm, outside of which is a layer ( $5^{-6}$ cells wide) of cork tissue, and whose outer border consists of radially elongated cells which form a conical cap to the scar (fig. 7). When collections of $T$. canadensis for this study were first begun, in the autumn

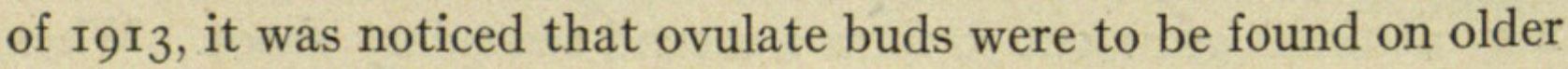
as well as on the current season's growth, as has since been pointed out for T. baccata by Miss AAsE (I). This is not due to dormancy of buds which had failed in development, as might usually be assumed, but to the persistence of the primary shoot year after year, producing one or two new secondary shoots each season. This renewal of growth is contemporaneous with that of the primary shoots of new branches, beginning early in the spring, although not becoming recognizable externally until later in the summer, when it can be distinguished by the slight projection which appears at the base of the secondary shoot (fig. 8). Growth is slow, and by the middle of July is arrested, as in previous seasons, by the growth of the new secondary shoot (fig. 9). As these observations show, the primary shoot is a persistent structure and may produce secondary shoots season after season, or become a leafy shoot, the situation being evidence against regarding the primary shoot with its secondary shoot as representing a compound strobilus.

TERMINAL PRIMARY SHOOT.-Several cases were found in which the primary shoot was a terminal structure of the leafy branch (figs. Io, II), the terminal bud having developed as a primary ovuliferous structure, bearing a secondary shoot. That this may continue to function as a primary shoot for more than one season is shown by the presence of a secondary branch scar a little 


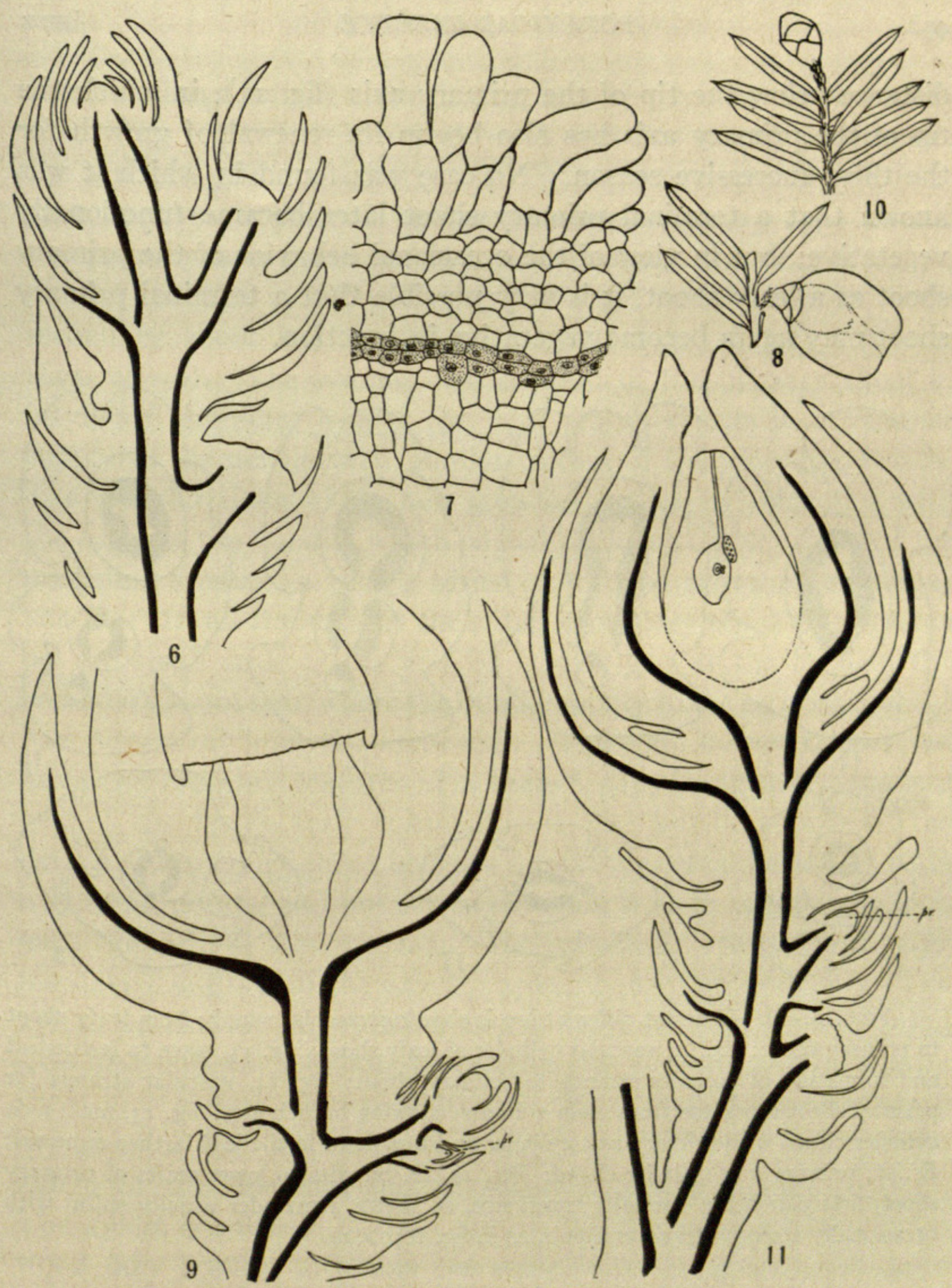

Figs. 6-Ir.-Fig. 6, long section of primary shoot showing scars of secondary shoots of two previous seasons; primary axis remaining dormant, not producing secondary shoot the season collected; $X_{24}$; fig. 7 , detail section through scar (note shaded abscission layer and corklike wound tissue external to it); $\times_{140}$; fig. 8 , primary shoot with mature ovule and projection at base of ovule showing external appearance of a normal second season's growth of primary shoot; fig. 9, longitudinal section of primary shoot showing half-grown ovule of current season and young ovule of next season (primary axis tip shown below younger ovule); $\times_{\mathrm{I} 7}$; fig. ro, terminal primary shoot; fig. II, longitudinal section of terminal primary shoot (leaf base shown at lower end of figure; note branch scar, left by secondary shoot of preceding season, and that primary axis tip has begun growth for third successive season); aril shown at base of ovule; $\times_{17}$. 
distance below the tip of the primary axis (fig. II), in which the tip of the primary axis has also begun its renewal of growth for the third successive season. No case was found in which it was known that a terminal primary shoot later became functionally vegetative; but in view of the occasional behavior of the primary shoot as a leafy shoot, it is very possible that a terminal primary shoot may again become vegetative in function.
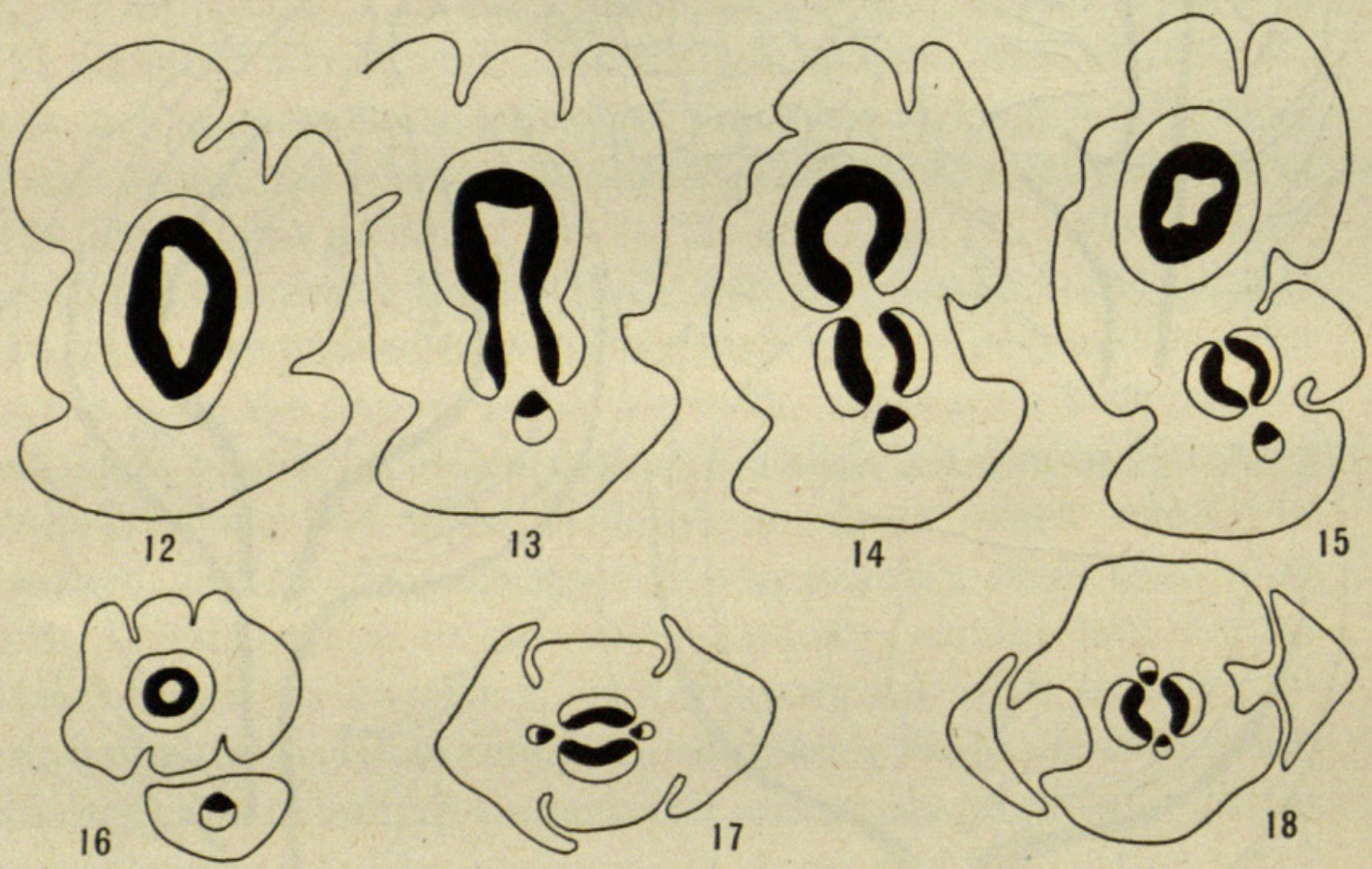

FIGS. I2-I8.-Series at different levels showing vascular supply from leafy shoot to primary shoot: fig. I2, vascular cylinder of leafy shoot; fig. I3 $_{3}$, trace to fertile leaf and formation of vascular strands to primary shoot; fig. 14, vascular strands for primary shoot separated from main cylinder, showing branch gap; fig. $1_{5}$, main axis cylinder closed with primary axis cylinder and bundle of fertile leaf farther removed; fig. 16 , primary axis cylinder closed; figs. 17,18 , bundles to lower scales of primary shoot, first pair being normally transverse, as shown, remainder usually spiral with occasionally a second transverse pair, as in fig. $18 ; \times 24$.

VAscular features.- Strasburger (35) was the first to describe the vascular supply of the primary shoot of $T$. baccata, and it is essentially the same in T. canadensis. The primary shoot receives two bundles from the axis of the leafy shoot (figs. I2-I5). These bundles meet at their edges (fig. I6) and form a complete vascular cylinder, which then gives off traces to the lateral scales (figs. I 7-20). At the level of the fertile scale the cylinder organizes 
into two large bundles, which pass into the axis of the secondary shoot (figs. 19-22), only a very weak vascular supply passing into the arrested primary axis tip. If there are two secondary shoots, each receives a pair of vascular bundles (figs. 23-27). Should the primary axis grow out into a leafy shoot the next season, a normal vascular cylinder develops, and the vascular supply to the secondary shoot has the usual features of an axillary structure (figs. 28-30). The normal continuation of the primary shoot in its dwarf character during the next season results in a vascular supply to the new growth, similar to that of the preceding season. The vascular tissue of the new growth develops in connection with the bases of the bundles which passed to the secondary shoot of the preceding season, so that a series of sections shows a continuous vascular strand throughout the entire secondary shoot axis, broken by the small scale traces and by a wide gap at the level of the secondary shoot scar, where the bundle supply to the secondary shoot had passed off from the main axis. This gap, however, does not have the ordinary features of a branch gap, being really the leaf gap of the fertile scale subtending it, the bundle supply of the detached secondary shoot being in lateral connection with the main axis at all points, and not separated from it as in ordinary branch gaps (fig. 32 ; cf. figs. 13,14 ). The previously arrested and rudimentary condition of the axis tip accounts for this behavior. The xylem portion of the cylinder is relatively narrow, growth being slow and uniform. Shoots more than one year old do not usually show any growth ring excepting in the region of the secondary branches of the preceding seasons, where the limit between the xylem of the first and second season's growth is very distinct. The xylem is endarch in the cylinder, but in the scales centripetal wood may appear, although the scale traces in general are quite short, frequently ending in the base of the scale.

MORPHOLOGICAL NATURE.-The morphological nature of the primary shoot has been the subject of some question. It seems clear that in Taxus the primary shoot is to be regarded as a vegetative shoot of limited growth, persistent for an indefinite period, producing secondary fruiting shoots season after season, as a dwarf shoot functioning only in this way. It may become a vegetative 


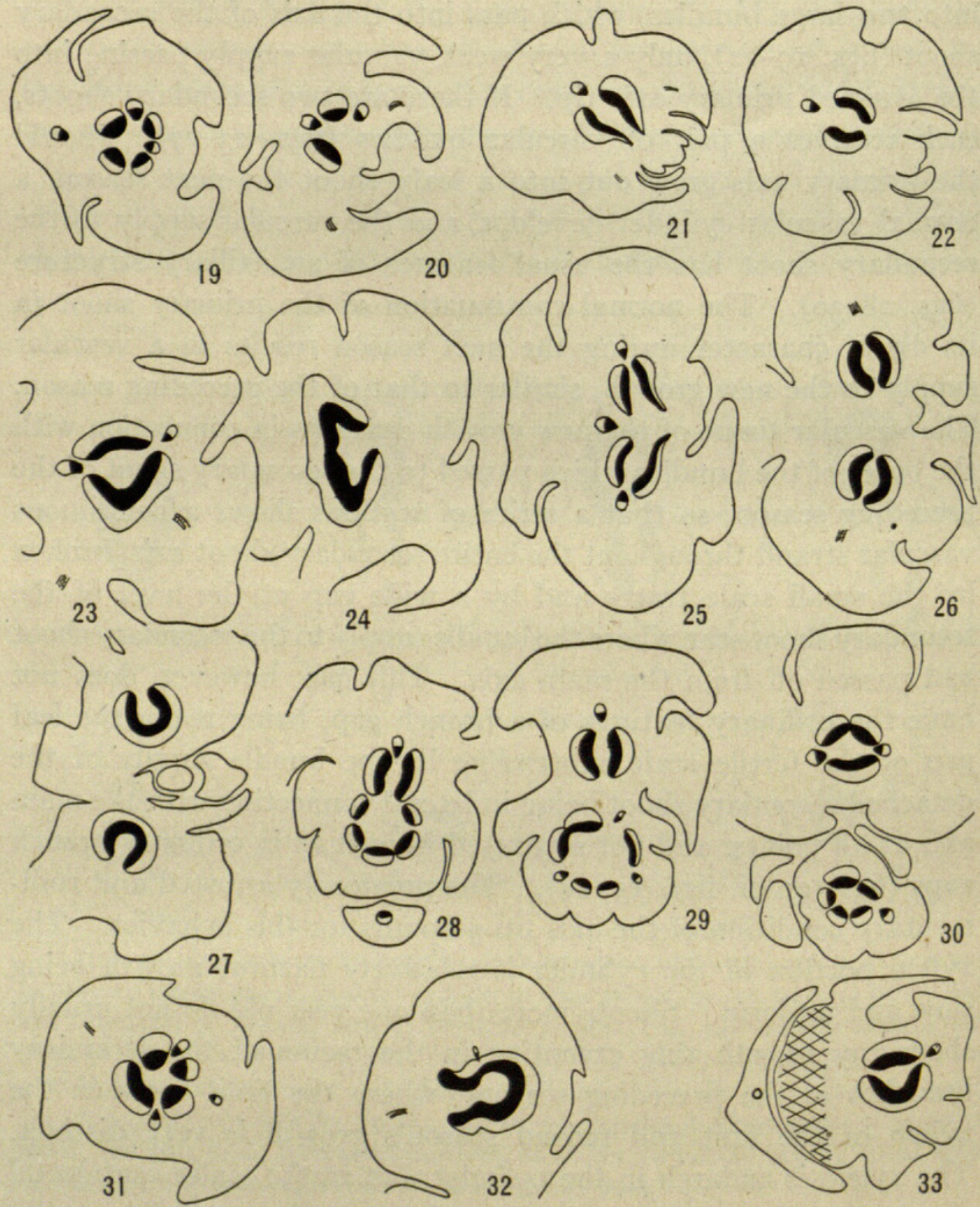

Figs. 19-33.-Figs. 19-22, series showing bundle supply from primary shoot to secondary shoot, also transition from normal primary cylinder (fig. 19) to organization into two bundles supplying secondary shoot (fig. 21); figs. 23-27, series showing vascular supply to two secondary shoots on primary axis; figs. $28-30$, series showing vascular supply when primary shoot becomes functionally vegetative second season; two large bundles of figs. 28 and 29 belong to secondary shoot, circle of small bundles to primary shoot; figs. $31-33$, series through primary shoot at least two years old, showing: fig. 31, usual primary shoot cylinder; fig. 32, large gap formed by bundle supply to secondary shoot (note that bundle supply to secondary shoot is laterally continuous with primary axis cylinder and has not formed branch gap as for normal axillary structure); fig. 33 , through branch scar (with crossed lines), and fertile scale; $\times 24$. 
shoot of unlimited growth, however, then having both the vegetative and reproductive possibilities of any other branch. The occasional behavior of the terminal bud in becoming a dwarf primary shoot recalls a similar behavior in Cinkgo, although one must not infer too much as to relationship on this account.

\section{Secondary shoot}

General FEATUREs. - The primordium of the secondary shoot first appears as a lateral structure in the axil of one of the uppermost scales of the primary shoot (fig. 34), soon becoming conical (fig. 35). It is generally stated that the terminal scale is the fertile one, but one or more small scales usually appear above the fertile one, as was pointed out in T. baccata by Van Treghem (37). Different writers have assigned definite scales of the primary shoot as the fertile one in T. baccata, VAN TIEGHEM claiming the eleventh, Strasburger (36) the eighth or thirteenth, and Pilger (23) the seventh; but this varies and is of no special importance. Frequently two of the scales are fertile and two secondary shoots occur, the tip of the primary shoot then appearing between them (fig. 36). In Torreya there are usually two secondary shoots on a primary shoot, but STRASBURGER's account that in rare cases in Torreya the primary shoot behaves as a secondary shoot, and bears a third ovule above the two secondary shoots, does not apply to Taxus.

The rudiment of the secondary shoot develops rapidly, producing the three pairs of decussate scales in rapid succession, the cyclic arrangement of which is in contrast with the spiral arrangement of the scales of the primary shoot. The first pair stands transversely to the fertile scale. Van TIEghem held that while the scales are decussate there is an indication of a spiral tendency, a view necessary to his theory that the ovule is an axillary structure of the sixth scale of the secondary axis. Practically all investigators agree as to the decussate nature of the scales, as there seems to be no basis for regarding the scales as having a spiral arrangement. The scales of the secondary shoot are considerably larger than those of the primary shoot, and contain chlorophyll, the outer epidermis being heavily cutinized, and stomata occurring on the inner surface. In the early stages these scales protect the young 
ovule, but shortly before pollination the tip of the ovule protrudes from between the scales, and with its development they become relatively less conspicuous.

\section{Ovule}

Historical.-The ovule of Taxus has been the subject of considerable discussion among botanists. The earlier taxonomists, such as Linnaeus (I7) and Jussieu (I6), regarded the ovule of

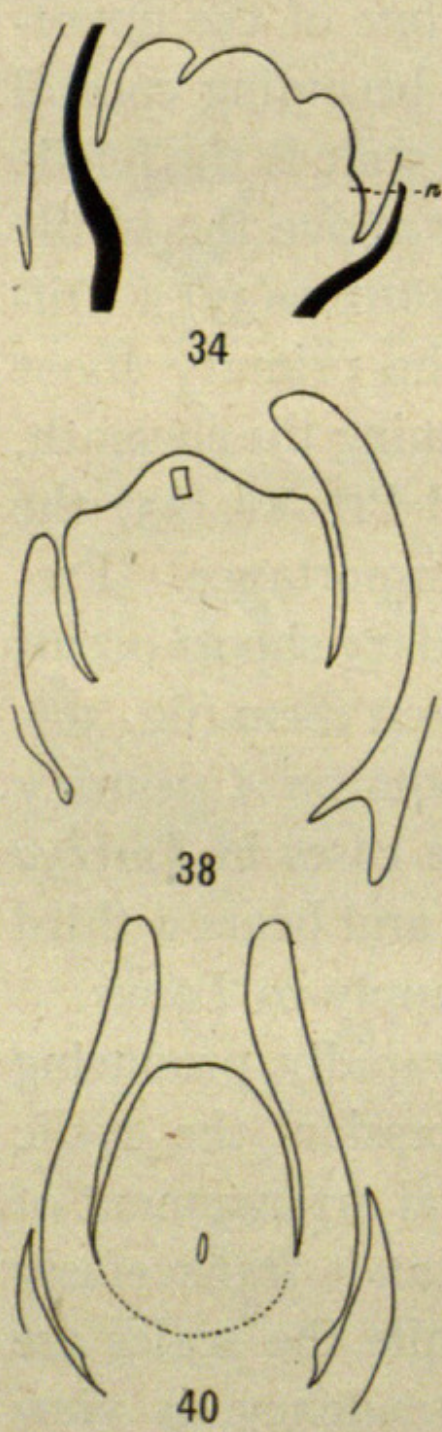

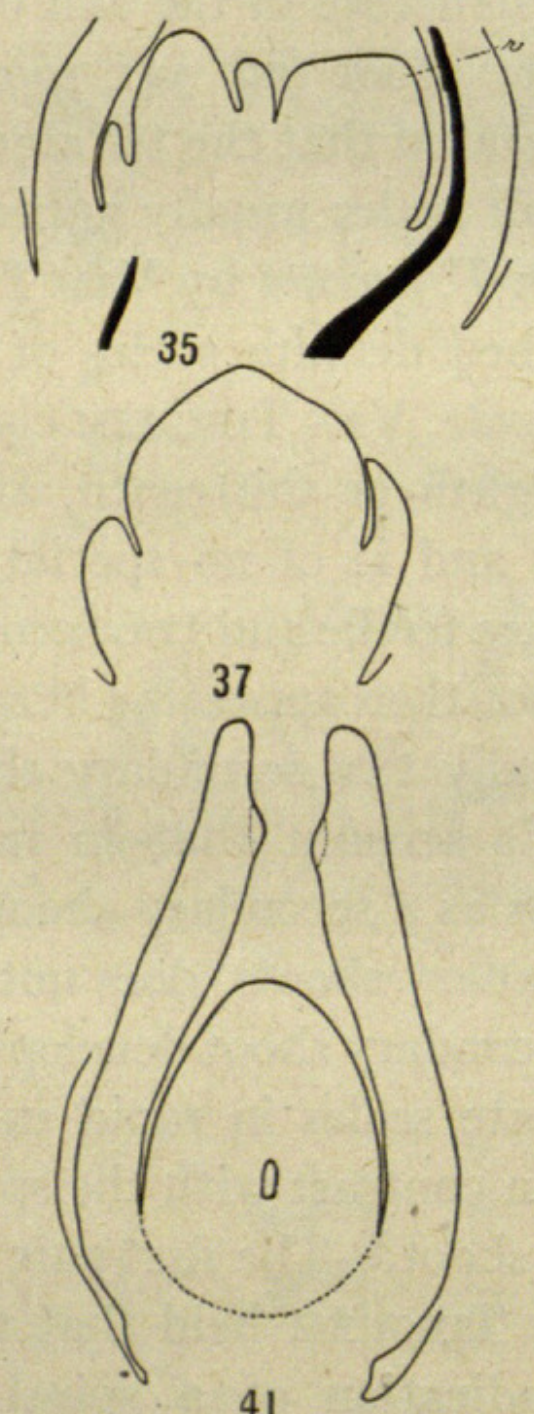

41

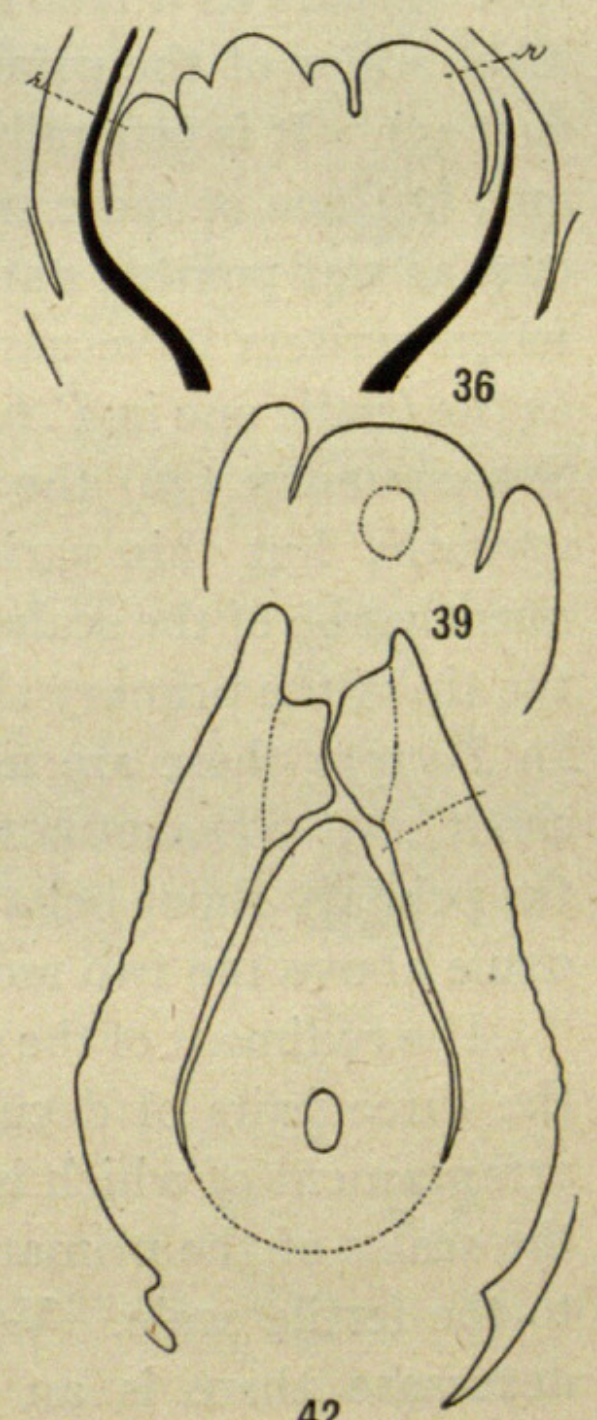

42

Figs. 34-42.-Fig. 34, long section of primary shoot showing lateral axillary rudiment $(r)$ of secondary shoot; fig. 35 , older stage, rudiment become conical; fig. 36 , rudiments of two secondary shoots, primary axis tip between; fig. 37 , axis tip of secondary shoot showing bulge indicating beginning of integumentary zone; fig. 38 , older stage showing integumentary zone more distinct and differentiation of archesporium (for detail see fig. 6r); fig. 39, older stage showing young integument and position of sporogenous tissue (inclosed by dotted line); fig. 40, young ovule about time of pollination, showing barrel-shaped integument and large open micropyle; figs. $4 \mathrm{I}, 42$, older ovules and closure of micropyle by plug tissue (for details see figs. 66, 67 ); figs. $34-39, \times 80$; figs. $40-42, \times 36$. 
all conifers as a pistil. TREw's observations, in 1767 , that the ovule of conifers receives the pollen directly, the representation of TREW'S observations by TARGIONI-TOZETTI in I8IO (RADAIS 24), and BROWN's (6) announcement of gymnospermy introduced a fertile topic for debate. For a time these newer views met strong opposition, RICHARD (25), for instance, declaring that there are no plants with naked ovules or without an ovary, and holding that the ovular integument was the perianth and the nucellus the pistil of the flower. BAILlon (2) was also a vigorous opponent, holding the ovule to be a 2-carpel ovary with a single orthotropous ovule. Parlatore (22), Sperk (34), with others, and even Strasburger (35) for a time also held to the ovarian theory of the ovule. Another group, among whom were SCHLeIDEN (29), A. BRAUn (5), SACHS (26), and others, accepted BROWN's view as to gymnospermy. STRASBURGER later accepted the same interpretation, and the question of the gymnospermy of Taxus has been generally accepted.

The morphological position of the ovule has not been so definitely settled, and it may yet be regarded as an open question whether it is a lateral structure, foliar in origin and only secondarily terminal, or a true terminal structure, unrelated to the scales in its origin. The first of these views depends upon the assumption that the ovule in gymnosperms must always be related to sporophylls, present or suppressed; the second that the ovule may arise from the axis itself, independent of lateral organs. Among the early workers SCHLEIDEN (30), SCHACHT (28), and others regarded the ovule as terminal to the branch. On the other hand, Don (II), CASPary (7), and others held to the foliar origin of the ovule. VAN TIEghem (37), using the anatomical method as a basis of interpretation, concluded from the orientation of the bundles that the ovule represents the first and only leaf of a shoot of the third order in the axil of the sixth bract of the secondary shoot, a view also accepted by Strasburger (35). SAchs (26) regarded the ovule as secondarily terminal, the bract nearest the ovule playing the rôle of the carpel, but later (24) changed his opinion, admitting the ovule to be terminal and a modified stem. Strasburger also abandoned his earlier position and held that the ovule is strictly terminal on the axis tip, that no relation to the last pair of scales 
can be found, and that there is no ground for VAN TIEGHEM's view. Magnus (18), pointing out the cauline origin of the ovule in Naias, spoke of it being similar to the situation in Taxus, in which he regarded the ovule as terminal. Later workers have more generally accepted the terminal nature of the structure. Celakovsky (8) held that the sporangium is terminal to the axis. WORSDELL (38) accepted and championed this view, stating that "anatomy points clearly to the fact that no axial foliar appendage of any kind exists upon which the sporangium is inserted, the cylinder of the axis being directly continuous into the base of the sporangium." JäGER (I5) speaks of the nucellus in $T$. baccata being formed by the vegetative tip of the secondary shoot. Miss AaSe (r), in a recent study of this problem, points out that the vascular supply to the ovule is "contrary to what should be expected" for an axillary structure. She also suggests the possibility of a fusion of sporophylls to form a single structure.

For a solution of the problem two groups of facts can be used directly, the origin and development of the ovule, and its vascular supply; the latter will be treated in connection with the vascular features of the secondary shoot as a whole. There are no known abnormalities with which one can compare the normal situation. Torreya apparently presents a similar situation, and thus gives no additional line of evidence.

ORIGIN OF OVULE.- The first indication of the ovular nature of the end of the shoot is the beginning of the integument as a ring around the tip of the axis (figs. 37,38 ), and the axis tip itself becoming the nucellus, as claimed by both STRASBURGER (36) and JÄGER (15) for T. baccata. There is nothing in the position of the ovule to indicate that it is a lateral structure, and so far as its ontogenetic origin gives a clue one must conclude that the ovule is strictly terminal, cauline in origin, and unrelated to any of the scales. If the scales represent sterile sporophylls phylogenetically, as is most probable, their sporophyll character has been completely abandoned and the axis itself becomes the sporangium, as in some of the angiosperms, where cauline ovules are not uncommon. That the vascular features sustain this view will be indicated later. 
Megasporangium.-In $T$. baccata Strasburger (36) pointed out the hypodermal origin of the archesporium, describing it also for Larix europea. In $T$. canadensis the sporogenous tissue is also hypodermal in origin, the archesporium becoming differentiated very early in the development of the nucellus while it is yet coneshaped and the integumentary zone in a rudimentary condition (figs. 38, 6r). It may consist of a single cell or a small plate of cells. The periclinal division of the archesporium results in the primary wall cell and the primary sporogenous cell (fig. 62). The wall cell, together with other adjacent cells of the nucellus, divides repeatedly by periclinal divisions, building up a considerable mass of tissue between the sporogenous tissue and the epidermis, the cells of this tissue being in radial rows, at the inner ends of which are the sporogenous cells (figs. 63-65). Morphologically this is the outer portion of the many+layered wall of the megasporangium, and together with the epidermis constitutes the upper portion of the nucellus. The later development results in a considerable mass of sporogenous tissue (fig. 64), out of which one or more cells function as megaspore mother cells (fig. 65), as pointed out in my previous paper (I2). While I have no preparations showing divisions of the primary sporogenous cells, the amount of sporogenous tissue present indicates that this takes place, contrasting with the situation in which the primary sporogenous cell functions as the megaspore mother cell, as is probable in most conifers.

GROWTH OF NUCELLUS.-By the formation of the integument the nucellus becomes limited to a knob, at first conical; but with the development of the megasporangium it soon becomes rounded. From the growth of the wall, as just described, there develops a considerable mass of tissue above the sporogenous tissue. At first this tissue seems to be uniformly meristematic, but later division becomes confined to the inner portions, the outer cells and the epidermis becoming radially elongated. I was not able to find any actual periclinal divisions of the epidermis, but the position of the cells in the layers next to the surface (fig. 65 ) would indicate such divisions as Strasburger (36) found in the development of the nucellus of $T$. baccata, giving a several-layered epidermis. The nucellus, therefore, is composed of two morphological entities, 
the epidermis and the sporangium. The nucellus increases in diameter by anticlinal divisions of both epidermis and sporangium wall. Basal growth takes place also, so that the sporogenous region becomes situated in the focal center of the oval nucellus (figs. 40-42). From this time greater meristematic activity occurs in the peripheral regions contiguous to the line where nucellus and integument meet, resulting in the enlarged base of the nucellus. The tapetal function of that portion of the nucellus immediately surrounding the developing gametophyte, and the digestion of the nucellar tissue in the enlargement of the endosperm have already been described (12). The growing endosperm presses upon and stretches the nucellus so much that at maturity it is but a thin layer surrounding the endosperm.

A feature of interest is the extent of the freedom of the nucellus from the integument. In the earlier stages of development the two structures are entirely free from one another, a condition which persists until about the time of fertilization. The chalazal region now becomes the center of great meristematic activity, resulting in the development of the aril and the zonal growth of nucellus and integument as a united structure, so that at maturity the freedom of the nucellus from the integument is only partial. HOFMEISTER's (14) statement that in T. baccata the separation between the "nucleus" (nucellus) and the integument extended entirely to the base was most probably based on young ovules. Freedom of nucellus and integument occurs in Paleozoic seeds belonging to the Cordaitales, such as Cordianthus, and is perhaps a primitive feature retained by most modern gymnosperms only during the early stages in the development of the ovule. That freedom of the two structures should persist longer in some forms than in others is not surprising, and has been regarded as having morphological significance. Taxus, Torreya, and some others are alike in retaining this feature for some time, the relative amount of it being correlated somewhat with the size of the seed, basal growth of the ovule being more extensive in some forms than in others. Oliver (2r) has called attention to the basal intercalary growth of the ovule in Torreya, which results in raising both nucellus and integument. He also suggests that the lower portion 
of the seed is phylogenetically younger than the apex, where nucellus and integument are free from one another, introducing a problem already suggested by STRASBURGER $\left({ }_{36}\right)$ as to the real limits of the morphological ovule.

INTEGUMENT.-The development and structure of the integument of $T$. baccata have been described rather completely by - Strasburger (35), Bertrand (3), and JäGer (15), and are not different in $T$. canadensis. The integument arises as a zone of meristematic tissue surrounding the young nucellus (figs. 37-39). Uniform growth in the entire zone results in a cylindrical, barrelshaped integument surrounding the young nucellus (fig. 40), and extending some distance above it. At first the integument is uniform in thickness, six or more cell layers thick. The integument is 2-lipped from the early stages in its development, the lips alternating with the upper pair of scales. This feature has led some workers to interpret the integument as two carpels, and others as the fusion of two sporophylls. This 2-lipped character persists to the mature seed, but probably has no more morphological significance than has a similar and more pronounced feature in the ovules of many other conifers, especially the Abietineae, in which no foliar significance is attached to this character.

Up to the time of pollination the micropyle is relatively large (fig. 40). At pollination it is filled with the pollination droplet. At this time the inner wall of the integument is smooth, but soon after pollination becomes closed by the centripetal radial growth of a portion of the inner epidermis of two sides (figs. 41, 42, 66, 67). Closure of the micropyle in this way takes place even if the ovule is not pollinated, my preparations showing no difference in this respect between pollinated and unpollinated ovules. JÄGER found cases in $T$. baccata in which the micropyle had not yet closed at the time of fertilization, although usually taking place soon after pollination. In Juniperus both Norén (20) and Nichols (I9) claim the failure of micropyle closing unless pollen of Juniperus has entered it, foreign pollen having no effect. Experimental data on this point would be of interest. It would seem that the pollination droplet would be a more likely growth stimulant in this region than the presence of a pollen grain on the somewhat distant nucellus, 
or of pollen tubes within the nucellar tissue. JäGER also speaks of a ring-formed thickening at the outer end of the micropyle, a feature not present in $T$. canadensis.

1. In its later development increase in thickness occurs below the tip region, while growth in length is largely the result of chalazal activity. In cross-section the young ovule is practically circular in outline, but as it develops it becomes more elliptical, and, especially in the upper portions, pronouncedly 2-ridged, the ridges corresponding with the lips. Frequently there are three ridges, occasionally four, the 2-lipped character, however, remaining constant. StRASBURGER records finding very rare cases of 5-ridged integuments. These ridges have been regarded as the midribs of fused sporophylls, but, as shown later, are associated with the vascular supply of the ovule and do not necessarily indicate a sporophyll character of the integument.

The histology of the integument has been accurately described for $T$. baccata by both Strasburger (35) and Bertrand (3), a description which will also hold for $T$. canadensis. Before the hardening of the seed coat the following regions (fig. 68) are to be recognized: (I) the outer epidermis of large papillate cells, covered with a very heavy cuticle; (2) the hypoderm, large thickwalled cells, which become filled with brownish-red contents and give color to the seed coat; (3) a sub-hypodermal layer of small radially elongated cells; (4) a thick tissue of small irregular cells, extending to the inner epidermis, next to which the cells are longitudinally elongated; and (5) the inner epidermis, which in the micropyle region forms the plug tissue (fig. 67 ), and below, as far as free from the nucellus, consisting of elongated thick-walled cells containing a dark staining material. Below the union of the nucellus and integument the boundary between the two is not distinct. Large secretory cells are abundant in the inner tissue, and along the 2-keeled sides the strands of vascular elements traverse the integument. Formation of the stony character of the seed coat begins at the apex and extends downward, involving all the tissue of the integument excepting the epidermis and hypoderm, the cells becoming "stony," with very thick walls pierced by protoplasmic connections (fig. 69). The hardening begins very soon 
after fertilization, and by. seed maturity has reached the base of the seed. In the meantime the aril has developed, surrounding the hard nutlike seed.

ARIL.- In the young ovule there is no indication of the aril, but about the time of pollination the aril primordium begins to develop as a ring at the base of the ovule (fig. 40). Its early development is contemporaneous with the chalazal growth of the ovule. In its early stages it is a flat saucer-shaped structure (figs. 5, II) of greenish color and of slow growth until the seed is nearly matured and the seed coat hardened. Then there is very rapid growth; it soon becomes cup-shaped and reaches its mature condition, that of a large red fleshy cup inclosing the hard seed (figs. 8, 43). The chalazal portion is a tissue of small cells, traversed by the vascular elements which supply the hard integument. The sides of the aril consist of "very large delicate-walled cells, filled with a watery material, the long cells being extended radially and obliquely upward. The epidermis is a narrow layer of small pigmented cells, and contains fairly numerous stomata, oriented longitudinally.

The morphological nature of the aril has been one of the mooted questions in the taxads, having been regarded as: (I) a special outgrowth surrounding the ovule, (2) a carpel, (3) representing the ovuliferous scale of other forms, (4) a second (outer) integument, and (5) the fleshy layer of a single integument. RICHARD (25) regarded the aril as the equivalent of the collar of Cinkgo, an accessory structure formed from the flower stalk. BLUME (4) thought of it as a carpel, and BAILLON (2) as an expansion of the axis surrounding the ovary. PARLATORE (22) seems to have been the first to regard the aril as the morphological equivalent of the ovuliferous scale of other forms, a view followed by CELAKovsky (8) and WORSDELL (39), both claiming the ovuliferous scale of conifers to be the morphological equivalent of the "epimatium" of the podocarps, of the outer fleshy layer of the ovule of Torreya and Cephalotaxus, and of the aril of Taxus. Sinnotr (33), in his study of the podocarps, holds a similar view with reference to Cephalotaxus, the logic of which would be to regard the aril of Taxus in the same light. Strasburger (35), with BAILlon (2), regarded the aril 


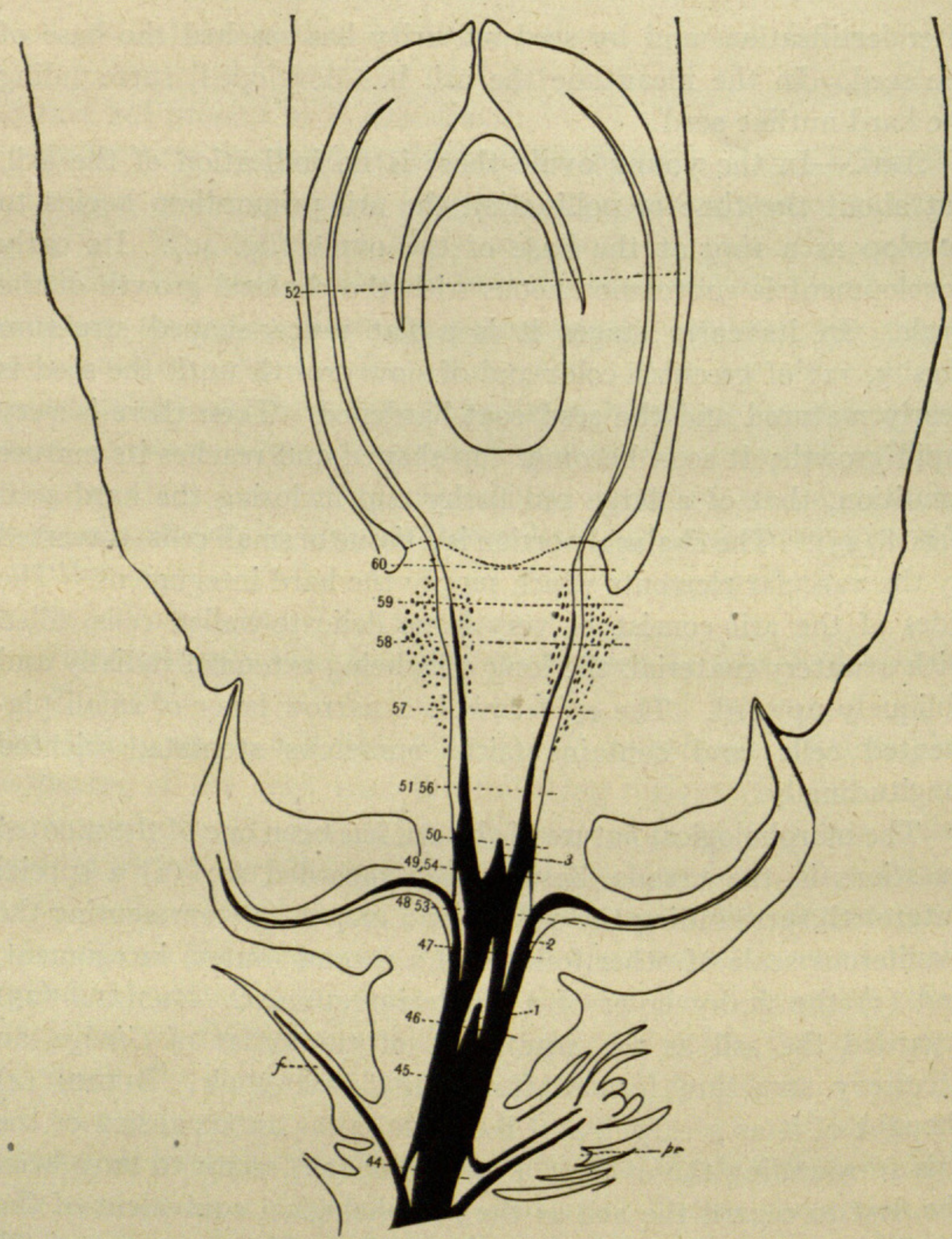

FIG. 43.-Semi-diagrammatic longitudinal section through primary shoot with secondary shoot and portion of mature ovule, $\mathrm{X}_{17}$; outlines of primary and secondary shoots and aril of ovule made with camera lucida, ovule inserted diagrammatically; outlines of vascular supply also made with camera; note young ovule of next season above primary axis tip $(p r) ; 1,2,3$, traces to $1 s t, 2 d$, and 3 d pairs of scales, second pair of which shown in section; $f$, fertile scale of primary shoot; whole vascular cylinder of secondary shoot shown in black, light portions showing gap̄s in cylinder formed by scale bundles; in base of aril and seed, relation of xylem and phloem shown as seen in long section, xylem black, phloem white; scattered tracheids described are shown by area of black dots; curved line at base of seed shows line of separation when seed is removed from aril, and limit of camera outline of slide from which drawing was made; figures at ends of dotted lines across vascular tract indicate cross-section drawings corresponding to these levels. 
as an outgrowth of the axis, discoid in nature, a view also held of the ovuliferous scale of other forms. BERTRAND (3) and SCHUMANN (3I) both held the aril to be a special structure, the former regarding it as a proliferation of the cortical parenchyma at the base of the integument (which he regarded as the equivalent of the ovuliferous scale). J ̈̈̈GER (I5) regards the aril as a second or outer integument, basing his argument on the similarity in origin of the integument and the aril.

It will thus be seen that the structure is one which has given considerable difficulty in its interpretation, some of the explanations being perhaps more ingenious than reasonable. The carpellary nature of the aril no longer held sway after the acceptance of the gymnospermy of Taxus. That the aril may be a special structure arising from the axis and having no morphological significance seems an unnecessary way of avoiding the problem, and while possible is hardly probable. The view which regards it as equivalent to the ovuliferous scale of other forms has more in its favor, the chief objections to the idea for Taxus being the cauline origin of the ovule, independent of any recognizable sporophyll, and the belated appearance of the structure. It is hardly reasonable for the ovule to be present for so long and to reach such an advanced stage in development before the appearance of the structure on which it is supposed to be produced. Accepting the aril of Taxus and the fleshy layer of Torreya and Cephalotaxus as homologous structures, there is involved the difficulty of explaining why the aril should be free in one form and organically attached in the others, if representing the ovuliferous scale in all. The entire absence of a vascular supply in the aril of Taxus, excepting the strands which pass through its basal portion, makes impossible an interpretation based on its vascular features.

The question of two integuments or one seems to be partly a matter of terminology. Distinction needs to be made between the idea of two integuments, an inner and an outer one, and the idea of a single integument of three layers, the outer fleshy one of which may be more or less free from the other two. Coulter and LAND (I0) have described the situation in Torreya taxifolia, and speak of the outer fleshy layer of the ovule as the outer integument. Concerning Torreya, Coulter and Chamberlain (9) state 
that "it is a natural thing to see in these three layers characteristics of the testa in cycads, Ginkgo, and the older gymnosperms; and to conclude that the two integuments have arisen from a single one by delaying the development of the region that becomes the outer fleshy layer. These facts and the inference seem to hold good also in the case of Taxus, the only difference being that the outer fleshy layer (aril in this case) remains distinct from the inner one." In Taxus this freedom of the aril and hard integument extends to the base (fig. 43), probably due to the fact that the development of the aril begins relatively late. COULTer and LAND's figure of the ovule of Torreya at the mother cell stage shows considerable growth of the fleshy layer, while a corresponding stage (fig. 40) in Taxus shows but the beginning of the aril primordium. In Torreya there is a much greater and earlier chalazal growth of the ovule, resulting in a larger seed than in Taxus, the bulk of which is produced below the point of juncture of the fleshy layer and the hard coat.

In Taxus the inner fleshy layer may be represented only by the inner epidermis, and possibly a few layers of cells in the basal portion of the ovule, and is practically absent. The remainder of the seed coat becomes hardened, with the exception of the epidermis and hypoderm. It hardly seems reasonable to regard these two layers of cells as representing the outer fleshy layer, but rather that their failure to develop the stony character is due to their superficial position. "The probability is that the stony layer would not develop superficially in any event, so that it would not be necessary to regard a layer or two of cells overlying it (the hard coat) as representing the outer fleshy layer (Coulter and Chamberlain 9, p. 4I8). The inference is that the outer fleshy layer is lacking in the Pinaceae, and from the same reasoning the outer layer of the seed coat in Taxus need not be regarded as an outer fleshy layer. Even the claim for two integuments in the old Cordaitean seeds is based on weak evidence, and the seed coat there "may correspond to the outer fleshy layer and stony layers of the single integument of cycads and Cinkgo" (Coulter and Chamberlain 9, p. I74). Scott (32) also calls attention to the possibility of this view. It is likely that only a single integument 
occurs in all known gymnosperms, excepting the Gnetales. In the older forms it is more or less distinctly differentiated into the three layers; in the modern forms one or more layers become "reduced," as the outer fleshy layers in most conifers and the inner fleshy layer in such forms as Taxus. On the other hand, the taxads are pronounced in the retention of the outer fleshy layer, Cephalotaxus, Torreya, and Taxus showing an excellent series both in the delay in appearance and in the freedom from the stony layer, Taxus showing both these features in greatest degree.

Attempts have been made to relate the taxads to the cycads on account of the fleshy character of the ovule, regarding Cephalotaxus and its relatives as bridging from cycads to conifers. The cycadean origin of the conifers does not harmonize with the known facts, however, and the attempt to relate all gymnosperms with fleshy seeds in a common phylogeny is almost as absurd as to attempt to construct a human "family tree" on the same basis. The tendency to "fleshiness" is too scattered to have any phylogenetic significance in a broad sense, although it probably has value within the narrower limits of small groups.

\section{VASCULAR FEATURES}

The vascular supply of the secondary shoot of $T$. baccata has been described by Van Tieghem (37), Strasburger $(35,36)$, and Miss AASE (I). VAN TIEghem was the first to apply anatomical criteria to the morphological nature of the ovule, and concluded from the origin, orientation, and structure of the vascular supply that the ovule is a lateral structure, representing the first and only leaf of a branch of the third order arising in the axil of the "sixth scale" of the secondary shoot. According to his description, after the fertile scale has received its vascular supply, two bundles leave the axis, turn in such a way that the xylem is oriented outward, and these two bundles then penetrate the ovule, where, after forming a "small vascular cup," they give off, ordinarily two, sometimes three, or even four or five, branches into the integument. $\mathrm{He}$ also gave the bilateral symmetry of the ovule as one of the reasons for regarding it as axillary, bilateral symmetry being characteristic of leaf structures as contrasted with stem 
structures. Strasburger (35) described the bundle supply to the three pairs of decussate scales and to the ovule, accepting VAN TIEGHEM's interpretation of the situation. Later he reversed his earlier view and regarded the ovule as terminal, there being nothing in the course of the bundles to give a clue to the lateral position of the ovule. He described the bundles in the integument as consisting of long, thin-walled elements, but containing no tracheids. Miss AASE describes the vascular supply to the ovule and the fusion in pairs of the four bundles from the axis as different from cases in which the united bundle is to supply an axillary structure, the pair consisting of "one bundle from each side of the bract bundle of the next lower pair, and not one from each side of the bract of the last pair." Miss AASE also pointed out the concentric character of the bundles in the base of the ovule, and the possible ending of one of the bundles before reaching the ovule. From her study the suggestion is made that there may have been a fusion of sporophylls to form a single structure, implying "the reduction of the ovules to one, the complete fusion of two sporophylls to the integument of the ovule, and finally the reduction of the vascular supply to each sporophyll to the single weak bundle in the wing of the ovule." She concludes, however, that "further investigation is necessary."

In $T$. canadensis the essential facts are not materially different from those of $T$. baccata, and a brief statement of the situation will be sufficient. The secondary axis receives two large bundles from the cylinder of the primary shoot (figs. 2I, 44), these uniting at their edges and forming a closed cylinder (fig. 45). The traces to the first pair of scales are given off near this level (fig. 46). Traces are then given off to the second pair of scales (fig. 47), above which the gaps formed by the first pair of traces are closed, giving again two large bundles in the cylinder (fig. 48). The bundles to the third pair of scales are given off directly above those to the first pair (fig. 40), these bundles being usually quite short, at times not even reaching to the scale, but ending in the cortex itself. The main cylinder now consists of four bundles, two on each side, the pairs being separated by the gaps formed by the third pair of scale bundles. The two bundles of each pair turn through an angle of $45^{\circ}$ and unite laterally (fig. $5 \mathrm{I}$ ), closing the gap formed by the second 


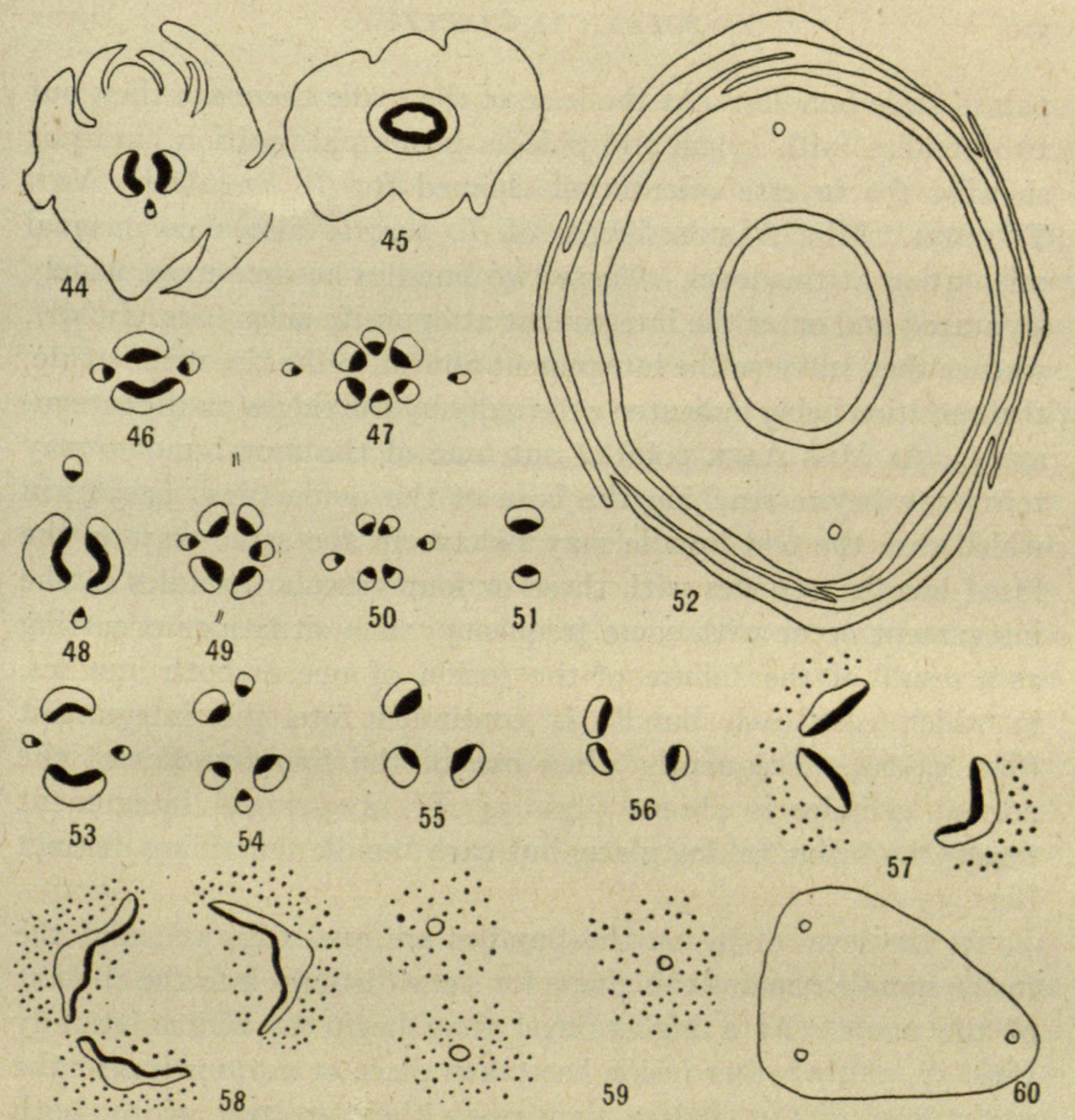

Figs. 44-60.-Figs. 44-52, series of transverse sections through young ovule (about age shown in fig. II) showing normal vascular situation at various levels, corresponding to dotted lines figured in mature ovule of fig. 43; fig. 44, two bundles from primary shoot; fig. 45 , closed cylinder; fig. 46 , bundles to first pair of scales; fig. 47 , bundles to second pair of scales; fig. 48 , cylinder above second pair of scales; fig. 49, bundles to third pair of scales; fig. 50 , cylinder of four bundles in base of ovule; fig. 51, two bundles resulting from pairing of four cylinder bundles; fig. 52, crosssection of young ovule, showing two vascular strands in integument and cyclic arrangement of three pairs of scales; $X_{24}$.

FIGS. 53-60.-Series of sections through mature secondary shoot and base of aril showing vascular supply to 3 -ridged integument and relation of xylem and phloem in mature condition (note corresponding levels in fig. 43); fig. 53, bundles to second pair of scales; fig. 54, to third pair of scales, one of four bundles of normal cylinder lacking; figs. 55-57, each of three bundles remaining distinct, becoming broader tangentially at higher levels, and in fig. 57 showing scattered tracheids outside phloem; fig. 58 , concentric bundle with narrow zone of continuous xylem next to phloem; fig. 59, concentric bundle consisting of small phloem strand surrounded by scattered tracheids; fig. 60 , three phloem strands as they pass from aril to seed; $X_{24}$. 
pair of scale bundles. At the base of the ovule there are then but two bundles, with xylem and phloem in normal position, and not showing the inverse orientation claimed for $T$. baccata by VAN TIEghem. Miss Aase's figures of $T$. baccata also show normal orientation at this level. These two bundles become more widely separated and enter the integument at opposite sides (figs. 43, 52), whence they traverse the integument almost to the tip of the ovule, their position being indicated externally by the ridges on the integument. As Miss AASE pointed out, one of the four bundles may terminate before reaching the base of the ovule (figs. 53-56), in which case the odd bundle may behave in the same way as the fused bundle. Ovules with three or four vascular bundles in the integument occur with some frequency, such situations occurring as a result of the failure of the fusion of one or both bundles, in which case each bundle is continued into the integument (figs. 53-60). Frequently when one of the four bundles of the normal cylinder is absent (figs. 54, 55) a 3 -ridged integument results, no fusion taking place, but each bundle remaining distinct (figs. 53-60).

At the level of fusion the bundles are oval (fig. $5^{\mathrm{I}}$ ), and the fusion bundle remains this shape for some distance into the chalaza of the ovule. At a higher level they begin to widen laterally (figs. $57,5^{8}$ ), whether fusion has taken place or not, until near the upper level of the chalaza they reach their greatest width, both radially and tangentially. They then suddenly become narrow, and pass into the hard integument as narrow strands (figs. 43, 60). The bundles are endarch throughout their course, and at the base of the aril are collateral. Higher up, however, scattered xylem elements, consisting of short spiral-marked tracheids with bordered pits, appear outside the phloem (figs. 57, 58), and in the upper portions of the aril base the bundles consist of the phloem strand surrounded on all sides by the loosely distributed short tracheids (fig. 59). The tracheids occur only in the aril portion of the chalaza, the bundles as they pass into the integument consisting only of few thin-walled elements of phloem tissue.

It would seem that the vascular supply to the ovule favors the interpretation of it as terminal and cauline in nature. The vascular 
supply arises equally from the two sides of the axis cylinder, the entire cylinder being involved in the supply. The bundles as they pair and fuse arise from opposite the second pair of scales and alternate the third pair of scales, an anomalous situation if the ovule were axillary to either of the third pair of scales. The ovule bundle supply is a direct continuation of the axis cylinder, the fusion of the bundles in the base of the aril closing the gap above the second pair of scale bundles. The orientation of the bundles is normal and presents no difficulty. The course of the bundles being opposed to the idea of an axillary origin is also against the view that there may have been a fusion of sporophyll with integument, and that the integumentary bundle is a vestige of that fusion. The presence of vascular bundles in the integument of gymnosperms is sufficiently common to cause no surprise in such forms as the taxads, nor is there any more argument for the sporophyll nature of the integument there than there might be in the cycads, where sporophyll and ovular integument are not confused, unless it be necessary to supply a theoretical sporophyll for a terminal cauline ovule.

The terminal cauline nature of the ovule is a much simpler interpretation of the facts, according both with the ontogenetic origin and the vascular supply. While this is an unual situation for a gymnosperm, it is not out of harmony with a tendency among the seed plants, a tendency expressing itself frequently in angiosperms and not necessarily impossible in gymnosperms.

\section{Summary}

I. The ovuliferous bud arises in the axil of a leaf early in the season, and matures the next year.

2. The ovuliferous organ consists of the primary shoot and the secondary shoot with the ovule.

3. The primary shoot is to be regarded as a vegetative branch of limited growth, bearing only reproductive axes (secondary shoots). While of limited character, at times it may become a functional vegetative shoot like any other vegetative branch.

4. The primary shoot is a persistent structure, functional for several successive seasons. 
5. Occasionally the primary shoot may be terminal to a leafy branch.

6. The secondary shoot consists of three pairs of decussate scales and a terminal ovule.

7. The ovule arises as a direct continuation of the axis, there being nothing in its origin to indicate that it is a lateral structure.

8. The archesporium arises from the hypoderm. The sporogenous tissue consists of a considerable mass of cells, out of which one or two may function as megaspore mother cells.

9. The aril is regarded as the morphological fleshy layer of a 3-layered seed coat, delayed in appearance and physically separate from the hard stony layer.

ı. The ovule receives its vascular supply direct from the axis cylinder, contrary to any axillary nature, and in harmony with the view that it is a cauline structure.

The writer acknowledges obligations to Professors JoHN M. Coulter and Charles J. Chamberlain, under whom the study of Taxus was begun.

Juniata College

Huntingdon, Pa.

\section{LITERATURE CITED}

I. AASE, HANNAH, Vascular anatomy of the megasporophylls of conifers. Bot. GAz. 60:277-313. figs. 196. 1915.

2. BaIllon, H., Recherches organogéniques sur la fleúr femelle des Conifères. Ann. Sci. Nat. Bot. IV 14: I86-199. pls. 12, I3. I860.

3. Bertrand, C. E., Etude sur la teguments seminaux des vegetaux phanerogames gymnospermes. Ann. Sci. Nat. Bot. VI 7:57-92. pls. 9-14. I878.

4. Blume, —, Rumphia. $3: 1847$ (as given by Strasburger 35 , and RADAIS 24).

5. BRAUN, A., Utber das Individuum der Pflanze. $18_{53}$.

6. BRown, R., Character and description of Kingia, a new genus of plants found on the southwest coast of New Holland, with observations on the structure of its unimpregnated ovule and the female flower in Cycadaceae and Coniferae. Trans. Linn. Soc. I825; Captain King's voyage, appendix b, Bot. pp. 529-559. London. I826.

7. CASPARY, R., De Abietinearum floris feminei structure morphologica. Ann. Sci. Nat. Bot. IX 14:200-209. 1860. 
8. Celakovsky, L., Die Gymnosperme: eine morphologish-phylogenetische Studie. Abhandl. Königl. Böhm. Gesell. Wiss. VII 4:I-48. I89o.

9. Coulter, J. M., and Chamberlain, C. J., Morphology of gymnosperms. Chicago. I9Io; revised edition. I9I7.

ro. Coulter, J. M., and LAND, W. J. G., Gametophytes and embryo of Torreya taxifolia. Bот. GAz. 39: I6I-I78. pls. I-3. 1905.

Ir. Don, DavID, Descriptions of two new genera of the natural family of plants called Coniferae. Trans. Linn. Soc. 18:163. 1839; also Ann. Sci. Nat. Bot. II 12:227-243. I839.

12. Dupler, A. W., The gametophytes of Taxus canadensis Marsh. Bot. GAZ. 64: II 5-I36. pls. II-I4. I9I7.

13. - The staminate strobilus of Taxus canadensis. Bor. GAz. 68:345366. pls. 24-26. figs. 22. I919.

I4. Hofmeister, W., Vergleichende Untersuchungen der Keimung, Entfaltung, und Fruchtbildung höherer Kryptogamen und der Samenbildung der Coniferen. pp. 179. pls. 33. Leipsic. I851; Eng. transl., London. I862.

15. JÄGER, L., Beiträge zur Kenntniss der Endospermbildung und zur Embryologie von Taxus baccata. Flora 86:24I-288. pls. 15-19. I899.

r6. Jussieu, A. L. De, Genera Plantarum. i788.

I7. Linnaeus, C., Genera Plantarum, I737; 6th ed. I764.

18. Magnus, P., Zur Morphologie der Gattung Naias L. Bot. Zeit. 27:769773. r869; also, Beiträge zur Kenntniss der Gattung Naias L. Berlin. I870.

19. Nichols, C. E., A morphological study of Juniperus communis var. depressa. Beih. Bot. Centralbl. 25:20I-24I. pls. 8-I7. figs. 4. I9Io.

20. NORÉN, C. O., Zur Entwickelungsgeschichte des Juniperus communis. Upsala Universitets Arsskrift. pp. 64. pls. 4. 1907.

21. Oliver, F. W., The ovule of the older gymnosperms. Ann. Botany I7: 45I-476. pl. 24. figs. 20. I903.

22. Parlatore, F., Studi organographica sui flori e sui frutti delle Conifere. Opuscula botanica. 1864 .

23. Pilger, R., Taxaceae in Engler's Das Pflanzenreich. I903.

24. Radais, M. L., Anatomie comparée du fruit des Conifères. Ann. Sci. Nat. Bot. VII r65-368. pls. I-15. I894.

25. Richard, L. C., Commentatio botanica de Conifères et Cycadeis. Posthumous work edited by his son, AchILle Richard. 1826. Stuttgart.

26. SACHS, J., Lehrbuch. I 868.

27. —, Lehrbuch. 2 d ed. 1870 .

28. Schacht, H., Lehrbuch der Anatomie und Physiologie der Gewächse. Theil II. I859.

29. Schlemen, M. J., Einige Blick auf die Entwickelungsgeschichte. Wiegmann's Archiv. p. 289. pl.8. I837; also, Beiträge zur Botanik. p. 26. 1837. 30. - Sur la signification morphologique du placentaire. Ann. Sci. Nat. Bot. II I2:373-376. I839. 
3r. Schumann, K., Utber die weiblichen Bluten der Coniferen. Abh. Bot. Ver. Prov. Brandenburg 44: 1902.

32. Scotr, D. H., Studies in fossil botany. 2 d ed. London. I909.

33. Sinnoti, E. W., The morphology of the reproductive structures in the Podocarpineae. Ann. Botany 27:39-82. pls. 5-9. I9I3.

34. Sperk, G., Die Lehre von der Gymnospermie in Pflanzenreich. Mem. Acad. Imper. Sci. St. Petersburg. VII 13: no. 3. I869.

35. Strasburger, E., Die Coniferen und die Gnetaceen. 1872.

36. - Die Angiospermen und die Gymnospermen. I879.

37. Van Tieghem, Ph., Anatomie comparée de la fleur femelle et du fruit des Cycadées, des Conifères, et des Gnetacées. Ann. Sci. Nat. Bot. V ro: 269304. pls. 13-16.' 1869.

38. Worsdell, W. C., Qbservations on the vascular system of the female "flowers" of Coniferae. Ann. Botany 13:527-548. pl. 32. I899.

39. — The structure of the female "flower" in Coniferae; a historical study. Ann. Botany 14:39-83. I900.

\section{EXPLANATION OF PLATE XXIII}

All figures were made with a camera lucida excepting figs. 2, 4, 8, 10, and part of 43. Text figures have been reduced to one-third and plate figures to one-half original size. The scale of magnification of the figures is shown in connection with the descriptions.

FIG. 6r.-Archesporial initial showing hypodermal position; $X_{475}$.

FIG. 62.-Two archesporial cells divided, each forming primary wall cell and primary sporogenous cell; $\times 475$.

FIG. 63.-Primary wall cells divided and beginning formation of megasporangium wall; $\times 475$.

FIG. 64.-Older nucellus showing several-layered wall and central mass of sporogenous tissue (detail of fig. 39 ); $\times 475$.

FIG. 65.-Portion of nucellus showing several-layered epidermis (cells without nuclei), megasporangium wall (cells with nuclei), and sporogenous tissue (shaded) with group of megaspores; $\times_{475}$.

FIG. 66.-Portion of integument showing beginning formation of plug tissue; $\times 210$.

FIG. 67.-Mature plug tissue; $\times 210$.

FIG. 68.-Detail showing integumentary regions, outer papillate epidermis with heavy cuticle, hypoderm of large cells, sub-hypodermal layer, and internal tissue; inner epidermis not shown; $X_{2}$ ro.

FIG. 69.- "Stony cells" from hard integument showing protoplasmic connections; $\times 2$ ro. 


\section{$2 \mathrm{BHL}$ Biodiversity Heritage Library}

Dupler, A W . 1920. "Ovuliferous Structures of Taxus canadensis." Botanical gazette 69(6), 492-520. https://doi.org/10.1086/332688.

View This Item Online: https://www.biodiversitylibrary.org/item/109453

DOI: https://doi.org/10.1086/332688

Permalink: https://www.biodiversitylibrary.org/partpdf/224585

\section{Holding Institution}

Missouri Botanical Garden, Peter H. Raven Library

\section{Sponsored by}

Missouri Botanical Garden

\section{Copyright \& Reuse}

Copyright Status: Public domain. The BHL considers that this work is no longer under copyright protection.

This document was created from content at the Biodiversity Heritage Library, the world's largest open access digital library for biodiversity literature and archives. Visit BHL at https://www.biodiversitylibrary.org. 